\title{
DETERMINANTS OF VERTICAL COORDINATION OPTION CHOICES AMONG SMALLHOLDER FRENCH BEANS PRODUCERS IN KENYA
}

\author{
Naomi Chebiwot CHELANG'A * (iD, Isaac Maina KARIUKI, Gideon Aiko OBARE
}

\author{
Address: \\ Department of Agricultural Economics and Agribusiness Management, Egerton University, P.O Box 536-20115, \\ Egerton-Njoro, Kenya \\ * Corresponding author: naomichebi09@gmail.com
}

\begin{abstract}
Research background: With market liberalization and the introduction of the new Global GAP measures, several vertical coordination options have emerged, presenting smallholder farmers with multiple market outlets. The choice of any vertical coordination option (VCO) is likely to be entwined by farm, farmer and vertical coordination attributes, yet the selection of an appropriate market outlet for delivering farm produce is not clear-cut.

Purpose of the article: This study determines factors influencing the choice of vertical coordination options among smallholder French beans producers in Murang'a South Sub-County

Methods: Using data from a sample of 215 smallholder producers, the study employed a multivariate probit model (MVP) to explain the determinants of vertical coordination option choices among French beans farmers in four wards located in Murang'a South Sub-County.

Findings \& Value added: The results indicate that the choice of vertical coordination option was significantly influenced by gender, household size, education stock, group membership, extension service, training access, farming experience, off-farm income, credit access, distance and market reliability. This implies that the promotion of collective action as an institutional tool for linking farmers to high-value markets, matters. These networks will aid in sharing knowledge, increasing borrowing power and thus, producers can improve French bean quality as required by the market. Additionally, financial institutions stakeholders should develop policies that favour the acquisition of credit at affordable rates. Further, the government with other relevant stakeholders should conduct more training on global gap standards.
\end{abstract}

Key words: vertical coordination; smallholder producers; multivariate probit model; french beans JEL Codes: C01; D81; Q13

\section{INTRODUCTION}

In recent times, the significance of cereals and other staple food crops is declining in developing countries, with highvalue commodities receiving an increasing demand. Highvalue products are commodities with high economic returns, such as cut flowers, fruits, vegetables, meat, milk and fish. Vegetable production being labour-intensive is considered to be an income-generating activity that fits well with the concept of smallholder agricultural development (Dilamini et al., 2019). French beans is one of the most crucial export vegetable produced by smallholder farmers in Kenya. Besides, it has a short life cycle, thus ensures income flow throughout the year. Recently, the French beans market has expanded, as seen in Kenya's supermarket shelves and wholesale markets.

Structural changes in the agri-food supply chain, development of institutions for vertical coordination, and growth of high-value commodities present opportunities for smallholder farmers (Nandi et al., 2017). In developed countries, vertical coordination options are well developed: thus, farmers make rational decisions on the choice of market outlet. However, in Sub-Saharan countries, in particular Kenya, vertical coordination options are weak, and as such, enforcement and choices are also spurious for smallholder producers. In addition, smallholder producers' farm produce is small in quantities that require aggregation. The aggregators are limited to buying companies or producer marketing organizations (PMO) that are most organized around a specific buyer or an NGO market-linked PMO. The supply chain has become an essential strategy for guaranteeing quality and reliable sourcing of fresh fruits and vegetables globally. Procurement between the producer and the buyer is usually based on observable features like size, volume and colour (Nandi et al., 2017). The choice to sell is not mutually exclusive. Producers would prefer to sell a large proportion of their output to the primary buyer while the rest to other buyers (Muthini et al., 2017; Mojo et al., 2017).

Besides, market liberalization has given smallholder farmers chances to diversify their production to target high-value markets, for instance, export and processing oriented markets. However, in liberalized markets, 
individual farmers lose negotiation power and are usually exploited by buyers due to imperfect information (Muthini et al., 2017). Farmers also face behavioural uncertainty due to the perishable nature of some agri-food products (Ciliberti et al., 2020). Therefore, Smallholder producers' participation in high-value markets remains a significant constraint. Empirical studies have shown that farmers need support from private and government sectors to access appropriate market channels (Nandi et al., 2017; Tarekegn et al., 2017).

The selection of appropriate market channels is an integral part of market participation decisions. Households' decisions to sell in different marketing outlets have a significant effect on income. Several factors are likely to influence farmers' decision to participate in any market outlets, including market access, prices, resource endowment and transaction cost (Tarekegn $\boldsymbol{e t}$ al., 2017; Mmbando et al., 2016). Understanding these factors is fundamental in pinpointing possible interventions necessary to assist farmers in maximizing benefits derived from production and marketing activities. Further, the information could help develop strategies required to mitigate the effect of some challenges, thereby facilitating smallholder producers' market entry and increasing their probability of running a lucrative crop investment (Abate et al., 2019). Besides, it increases income and alleviates poverty among rural households (Hung and Bokelmann, 2019). Every single market outlet is characterized by different risks, cost structure, profitability and other necessities. These features are essential to smallholder farmers who aim to access profitable channels (Abate et al., 2019). Muricho et al. (2015) suggested that understanding the association between market outlets is essential in profiling the channels and creating policy interventions cautiously designed to benefit the farmer.

Research on determinants of smallholder market choice has attracted the attention of many empirical studies in recent times (Kiprop et al., 2020; Mulbah et al., 2020; Abate et al., 2019; Dessie et al., 2018; Slamet et al., 2017). Given the potential of Murang'a County in French beans production, these study results are essential in providing vital information concerning appropriate vertical coordination options. Therefore, this study contributes to the literature by determining the factors influencing French beans channel choices among smallholder farmers. The study is predicated on time inconsistency in the choice of channels i.e., depending on the market situations on any given day or week, a smallholder could choose a channel or combination of channels to maximize returns. This inconsistency in the choices made is exacerbated by weak contract enforcement mechanisms when procuring from numerous smallholders producing a homogeneous commodity like French beans. Further, the market imperfections for instance, missing, incomplete and thin markets that dominate developing countries' commodity markets might generate less formal and complex arrangements compared to well-developed market systems in developed countries. Of more importance too is the poverty situation in rural farming set ups like Murang'a that might influence choice of more certain channels for pushing sales into the market and consequently quick cash, than relying on more stable relationships created over time, since the latter breed dependency syndrome.

\section{LITERATURE REVIEW}

\section{Overview of vertical coordination options}

Many studies have argued that vertical coordination strategies lie along a continuum running from spot market to full vertical integration. There are five major vertical coordination options: Spot markets are the simplest, and the intensity of coordination is low. The unseen hand of the market determines the price and broadly accepted standards. The parties involved only engage in price discovery and decide whether or not to enter into the transaction. In this sense, the opportunity to exercise control occurs entirely ex-ante to the transaction. The $e x$ post control decision is whether to repeat the transaction with the same party in the future (Peterson et al., 2001). The second strategy is specification contracting. This consists of advanced agreements committing farmers and buyers to specific transactions. They include market contracts where buyers stipulate market specifications such as quality, quantity, pricing and timing while leaving production choice to farmers. In resource-providing contracts, farmers are provided with essential inputs and sometimes production advice (Vroegindewey et al., 2018). The intensity of control is more than that related to the spot market. The parties involved exercise control through the ex-ante negotiation of contract specifications and mutually agreed on incentives for meeting the terms (Peterson et al., 2001).

The third portion of the continuum is the relationbased alliance, which is defined as an exchange relationship in which the firms involved share risks and benefits emanating from mutually identified objectives. The parties agree to work closely together and thus find means to resolve internal differences and concerns as they remain independent entities. The intensity of coordination is higher than that of the spot market and specifications contracting. When benefits fail to materialize, the alliance is likely to dissolve because of the ease with which both parties could walk away (Vroegindewey $\boldsymbol{e t}$ al., 2018). A strategic alliance is an example of this vertical coordination option.

The equity-based alliance is the fourth position along the continuum. It involves some level of shared equity assets among the parties in an exchange relationship. The existence of the new formal organization intended to conduct transactions is one of the distinguishing features of this form of alliance. The defining of decision rights and responsibilities is more precise than in a relation-based alliance. Although the ability to walk away has been reduced, the control is decentralized among the ownership parties. The parties still maintain their separate entity, which allows them to walk away if they so desire. In this strategy, the ex-ante activities focus on the legal formation of the new entity, while the ex-post control is through the board of directors that sets policies and procedures for executing all transactions (Bitsch et al., 2020). Agricultural cooperatives and joint ventures fall under this alliance. 
Full vertical integration is the final portion of the continuum, which involves a combination of two or more separable stages of production and marketing under common ownership and management. These stages include production, distribution, sales and other economic practices (Ayinde et al., 2017). It is characterized by centralized decision-making, high asset specificity and extensive information sharing. The advantage is that farmers can reduce transaction costs related to search for buyers. For ex-ante in this case, the control process involves negotiating the formal centralized ex-post governance structure. The ex-post control aims to achieve effective governance policies and procedures for the centralized entity (Peterson $\boldsymbol{e t}$ al., 2001).

\section{Determinants of vertical coordination option choices among farmers}

Using a binary logistic regression model in Indonesian vegetable market participation, Maspaitella et al. (2018) found that education level, age, land size, family size and farmer group association were statistically significant in determining supermarket contract participation. These findings were similar to that of Schipmann \& Qaim (2011) where the logit regression showed that age and household size statistically influenced women membership in a farmer cooperative. However, irrigation method, farm experience, distance to the market, average price, access to credit, extension service and access to market information were not statistically significant. The income obtained from vegetable farming was found to correlate positively with market participation. The authors suggested that prioritizing agricultural development strategies would increase farmer's involvement in the high-value market. These options included improving the technical innovations and empowering collective actions through farmer groups or cooperatives. In their study, the authors assumed that contract farming was homogenous, where farmers decided whether to participate or not. This approach is restrictive where multiple vertical coordination options are available; hence this study employed a multivariate probit to overcome this weakness.

Wollni et al. (2012) used a bivariate probit model to identify the determinants of farmer's participation in written and verbal contracts in the Costa Rican pineapple sector. The model results indicated that older, more educated farmers in group organizations were more likely to participate in a formal contract scheme. On the other hand, farmers with off-farm activities and access to credit from other sources were less likely to participate in formal contracts. Furthermore, more experienced farmers and the lesser the period a farmer had interacted with the buyer, the less likely they engaged in a formal agreement. The study also observed that participants in the verbal contract were more likely to be less educated and younger households with a larger number of male adults. Finally, the findings revealed that land size was not significant in either of the equations and hence there was no evidence for the exclusion of the smallholder farmers from verbal and written contracts. Thus, the model in this study is appropriate where there are two mutually inclusive outcomes.
Using the double hurdle model in the study of farmer's participation in the Zambian dairy interlocked contractual arrangement, Kiwanuka et al. (2016) found that smallholder's decision to participate in this arrangement was influenced by milk price, proximity to a water source, land size, ownership of non-land asset, net income, access to market information, number of lactating animals and ownership of improved breeds. The marginal effect indicated that any extra improved breed to the herd was associated with a $58.4 \%$ increase in the household probability of engaging in the program. Likewise, the increase in the processors' prices led to a rise in the households' probability to participate by $50.4 \%$. Similarly, access to market information and an increase in the value of non-land assets was associated with an increase in households' prospect to participate in the program. However, the limitation was that it only focused on one vertical aspect, the contract option. Therefore, this study included other vertical coordination options in the analysis to inform policymakers appropriately.

Carillo et al. (2017), in their survey on the choice of vertical coordination options, used a probit model which included; economic characteristics of the household, farm structure, and social-demographic features. The results indicated that various factors influenced a farm to be vertically coordinated as follows; large land size, high education level of the producer, household income, and product certification presence. The findings further showed that households headed by a male were more likely to be vertically coordinated than female headed households. A key factor that may explain this difference is the existence of gender gap in Sub-Sahara Africa with respect to extension services. The extension services tend to favour men over women. Consequently, men end up having better access to training, superior technology and are equipped with skills that assist them to participate in high value markets such as contract farming (Agholor, 2019). This was consistent with findings found by Nyaupane \& Gillespie (2011), where the probit results showed that age, education level and income affected the producer's choice of a market outlet. The limitation to this study is that the authors assumed that farmers had only one market choice to decide whether to participate. Therefore, this study included more market options to improve on the mentioned drawback.

In a similar study on factors that influence marketing decisions, Carillo (2016) used a linear regression model in the Italian Pasta supply chain. The findings indicated that gender and age did not affect the type of market option selected, and hence both coefficients were statistically insignificant. However, the education level or the number of training attended increased vertical coordination levels of the producers. The results showed low participation of smallholders into contractual arrangements as processors were discouraged from including them due to their inability to meet quality and quantity requirements. Consequently, other scholars argued that food companies prefer to work with medium and large producers (Singh, 2002). This model assumes linearity in parameters, while in reality, parameters are not always constant across time units. 
Trifkovic (2016) used a multinomial logit model to analyse the predictions of different vertical coordination mechanisms in Vietnam. From the findings, the choice of vertical coordination options was determined by transaction cost, weak contract enforcement, social norms, trustworthiness, perceptions, reliability, age and education level of the household. The study found that young and more educated farmers had greater opportunities to benefit from contracts, as observed by (Barrete $\boldsymbol{e t}$ al. 2012). In a similar survey, Abasimel (2020) recommended interventions towards rural education, training and improving financial institutions to facilitate market access. This model is appropriate when individuals only choose a single option from the established set of mutually exclusive choices. However, the model also assumes independence of each choice hence does not allow correlation between them. This study overpowered this weakness by using a multivariate model.

In examining the implication of contract farming for welfare and food security in China, Islam et al. (2019) used a probit model to determine factors that influence farmer's participation in contractual arrangements. The results from the study indicated that land size did not seem to be a barrier against smallholder participation. The factors that influenced farmer's participation included distance to the input and output market, farming experience, herd size, family member marital status, the price received before the contract, access to credit and extension service. Using a similar model in the analysis of factors that influence farmer participation in a cooperative in Germany, Pascucci \& Gardebroek (2010) found that, number of cooperatives within the vicinity of the farmer, wealth and better networking had positive impacts on horizontal integration decision. These studies focused on one vertical coordination option, whereas this study included other vertical coordination options as a basis of analysis.

A Multivariate probit model was used to determine factors that influence farmers' preference for pepper market outlets. In their study, Wosene et al. (2018) found that the sampled household made their choices depending on the following factors; farmer's experience, frequency of the extension contacts, education level, value addition, total livestock owned, quantity of pepper and distance to the market. The author further found that market contracts and consumer market outlets had a complementary relationship. The findings in this study were in line with that of Burkitbayeva \& Swinnen (2020), which also found that extension service contributed to developing skills and knowledge of the farmer hence adopting a closely coordinated supply chain. This model stands to be appropriate for the proposed study because it allows smallholder farmers to choose more than one option simultaneously.

In a study on determinants of market participation among smallholder pineapple farmers, Sigei $\boldsymbol{e t}$ al. (2014) used Heckman two-stage selection model to determine the decision to participate and the extent of participation in a high-value supply chain. The model involved two stages, firstly the selected equation was estimated using a probit model and secondly, the ordinary least squares regression method was used to estimate the outcome equation. The findings indicated that age, gender, marketing experience, price information, group marketing, yield and education level influenced farmers' participation in high-value markets. The results showed that $53 \%$ of the producers were under contracts while $43 \%$ did spot market transactions. The two-tailed results revealed that age was statistically significant at $1 \%$, indicating that market participants' mean age was less than non-participants. This result is consistent with that of Barrett (2010), which also concluded that the young people participated more in the market because they were more receptive to new ideas less risk-averse than older people. One weakness with this model is that it performs poorly when the normality assumption is violated.

\section{DATA AND METHODS}

\section{Study area}

The study was carried out in Murang'a South Sub County. The total area of Murang'a South Sub-County is 456.9 sq. Kilometers with a population of 184,824 people (KNBS, 2019). The Sub County is located between Longitudes 37 '08' 60" East and Latitude 0 ${ }^{\circ} 43^{\prime} 0$ " North. Murang'a South Sub-County comprises 6 wards, namely Kimorori, Makuyu, Kamahuha and Ichagaki. The area receives an annual average rainfall of $1164 \mathrm{~mm}$ and an annual temperature of $19.8^{\circ} \mathrm{C}$. It experiences long rains in March, April and May, with short rains being recorded between October-November. Agriculture is the main economic activity in the region, and it contributes to about $57 \%$ of the county's population income. The major cash crops in the county include tea, coffee, avocados, mangoes and macadamia. Horticultural crops include French beans, tomatoes, cabbages, kales and spinach, while food crops include bananas, maize, sweet potatoes and cassava (County Government of Murang'a, 2018).

\section{Sampling and sampling procedure}

Using a multistage sampling technique, a total of 215 farmers was obtained. At the first stage, Murang'a County was selected purposively since French beans are one of the three priority value chains that the county is promoting. It is also one of the few counties where the export of horticultural produce is a significant economic activity. At the second stage of sampling, Murang'a South SubCounty was purposely selected because it leads in French beans production and has the highest number of smallholder farmers. At the third stage, four wards namely, Kamahuha, Makuyu, Kimorori and Ichagaki were purposively selected based on the production level. At the fourth stage, two management systems (contract and noncontract farming) were purposively selected from each production ecologies. As suggested by Yamane (1967), when the study area's population size is known with certainty, the following formula is appropriate to determine the sample size Eq. (1).

$$
\begin{aligned}
& n=\frac{N}{1+N\left(e^{2}\right)} \\
& n=\frac{937}{1+937\left(0.06^{2}\right)}=214.3 \approx 215
\end{aligned}
$$


Where:

$n$ is the sample size, $N$ is the total population of interest and $e$ is the allowable margin of error. This gives a sample size of 215 respondents. French beans farmers were proportionately selected since the population in each ward was not equal in size. Finally, simple random sampling was used to select the 215 respondents.

\section{Empirical model specification}

Based on empirical studies reviewed, and considering time inconsistency, market imperfections and poverty condition as a possible motivation for the choice of vertical condition options in a rural set up like Murang'a, a multivariate probit model was adopted for this study. This model is preferred since it has the ability to simultaneously set out the influence of a set of explanatory variables on the choice of vertical coordination options while allowing the unobserved disturbances as well as different coordination options to be correlated (Belderbos et al., 2004). Smallholder farmers in this study are faced with different vertical coordination options like contracts, middlemen and spot market transactions. The producer's decision for any vertical coordination option is based on utility maximization. This implies that the alternative choice requires different costs and benefits and hence different utilities. Considering the possibility of simultaneous choices of vertical coordination options and the potential correlations among these coordination option decisions, a multivariate probit model stands to be appropriate. The model also helps to capture household variation in the choice of vertical coordination and to estimate several correlated binary outcomes jointly.

Other studies used a multinomial logit model in determining factors influencing producer's vertical coordination choice. The use of this model is misleading because it assumes individuals choose only one option from mutually exclusive alternatives. The choice of vertical coordination $j$ is dependent on the selection of the other. This is because smallholder farmer's choice decisions are interdependent.

Empirically this model can be presented as Eq. (2).

$Y_{i j}^{*}=\beta_{i j} X_{i j}+\varepsilon_{i} \quad\left(j=Y_{1}, Y_{2}, Y_{3}\right)$

Where: $Y_{i j}^{*}$ is the latent variable, $Y_{i j}$ is the observed dummy variable for all the options Eq. (3).

$Y_{i j}=\int_{0}^{1}$ if $\underset{\text { otherwise }}{Y^{*>0}} j=Y_{1}, Y_{2}, Y_{3}$

$X_{i j}$ is a set of explanatory variables, $B_{i j}$ are the coefficients to be estimated, $Y_{i 1}=1$ if a farmer chooses contract, 0 otherwise $Y_{i 2}=2$ if a producer selects middlemen, 0 otherwise, $Y_{i 3}=3$ if spot market is taken, 0 otherwise while $\varepsilon_{i}$ is the error term.

In a multivariate approach, the use of various vertical coordination options simultaneously is possible and the disturbance terms jointly follow a multivariate normal distribution with a mean of zero and a variance normalized to unity Eq. (4). $\left(\begin{array}{c}\varepsilon_{i 1} \\ \varepsilon_{i 2} \\ \varepsilon_{i 3}\end{array}\right) \ldots N\left(\begin{array}{l}0 \\ 0 \\ 0\end{array}\right)\left[\begin{array}{ccc}1 & P_{i 12} & P_{i 23} \\ P_{i 21} & 1 & P_{i 23} \\ P_{i 31} & P_{i 32} & 1\end{array}\right]$

Where:

$P_{i}$ represents the correlation between different vertical coordination options, $\varepsilon_{i 1}$ to $\varepsilon_{i 3}$ are the error terms. The off-diagonal elements in the covariance matrix represent the unobserved correlation between the stochastic components of different vertical coordination options.

Table 1 provides variables hypothesized to influence the choice of vertical coordination option.

\section{Post estimation test methods}

Variance inflation factor (VIF) was used to test the presence of multicollinearity while the Breusch-Pagan test was used to test the presence of heteroscedasticity. The presence of multicollinearity causes the estimated regression coefficients to have incorrect signs that could lead to wrong conclusions. Correlation among categorical variables was determined using a pairwise correlation test.

\section{RESULTS AND DISCUSSION}

Table 2 provides descriptive statistics of continuous household characteristics while Table 3 gives descriptive statistics of farm and farmer characteristics for categorical variables. The age of the sampled households ranged from 21 to 75 years. The mean age of the households surveyed was 46 years. This implies that most farmers are still in their productive age. According to Table 3, the majority of the respondents were males $(61 \%)$ which could be attributed to the fact that most males have land ownership rights relative to females. Education level was defined by the number of formal schooling. The overall mean education stock for the households surveyed was 38 years. A higher number of formal schooling among the households means that they are more receptive to new management practices and technologies. Household size was used as a proxy variable for the labour force and household dependency ratio. The results indicated that the mean family size of the sampled households was 4.4 with an adult equivalent ratio of 3.9. Farm size was assumed to be a good proxy gauge of wealth. The mean land size among the respondents was 1.26 acres implying that landholdings are very small. The small farm sizes generally suggest that majority of farmers are poor. Credit access was also inadequate (KES 2604) suggesting that farmers received low amounts of credit due to lack of collateral. Agricultural extension service is essential in informing and influencing farmers' decisions, especially in the adoption of new technologies. Sixty-one (61) percent of the farmers received extension services while the number of training received on average was 3.3 times for the last production year. Out of the sampled households, $(62 \%)$ of the key production decision-makers were members of agricultural groups. Horizontal coordination assists smallholder farmers in pooling resources to achieve economies of scale, thereby increasing their access to input and output markets. Group membership also aids farmers to attain bargaining power thus they can negotiate for better prices for their produce. 
The mean of farming experience was 10.33 years among the farmers. Producers who possess many years of farming experience have a better understanding of market opportunities and are less likely to be cheated since they know the market outlet dynamics. The association between farming experience and usage of vertical coordination options was statistically significant at $1 \%$. In terms of distance, farmers reported a mean of 3.8 Kilometres to the output market. A longer distance to the output market is associated with high transport cost thereby farmers were likely to choose market outlets that would reduce transaction cost. Concerning vertical coordination attributes, the availability of the channel had a mean score of 3.6 while that of reliability was 3.3. This implies that farmers who participated in vertical coordination options they perceived to have the highest attribute score.

Farmers participated in either a single choice or a combination of outlets. The six identified options include contract (38\%) middlemen (13\%), spot (8\%), contract and middlemen (8\%), middlemen and spot (17\%) while contract, middlemen and spot market at $16 \%$. Contracting was the dominant marketing outlet among farmers as shown in Figure 1.

\section{Post estimation test results}

The VIF mean value was 1.75 ranging from 1.06 to 3.75 . Based on the threshold of 10 the study found the absence of multicollinearity.

The probability chi-square was 0.2828 which is greater than 0.05 suggesting that heteroscedasticity was not a problem. We fail to reject the null hypothesis that the variance is homoscedastic.

Results on the correlation among categorical variables are given in Table 4 . The pairwise correlation values for categorical variables ranged from 0.0225 to 0.2593 which is below the acceptable cut-off point of 0.5 . This implies that there was no strong association among the categorical variables used in the model.

Table 1: Description of variables used in the study

\begin{tabular}{|c|c|c|c|}
\hline Variable & Description & Measurement & Expected sign \\
\hline \multicolumn{4}{|l|}{ Dependent } \\
\hline$Y_{i}$ & $\begin{array}{l}\text { Choice of vertical coordination, } \\
1=\text { contract, } 2=\text { spot, } 3=\text { middlemen }\end{array}$ & Categorical & \\
\hline \multicolumn{4}{|c|}{ Independent } \\
\hline Age & Age of HH head(years) & Continuous & + \\
\hline Hhsize & Household size(adult equivalent) & Continuous & $+/-$ \\
\hline Gender & Sex of the household head, $1=$ male, $0=$ female & Dummy & + \\
\hline Edu & Education stock (years of formal schooling) & Continuous & + \\
\hline AccCrdt & Amount of credit (KES) & Continuous & + \\
\hline Fsize & Farm size (in acres) & Continuous & + \\
\hline Offincome & Off-farm income & Continuous & + \\
\hline ExtAcc & Extension access & Dummy $1=y e s, 0=$ no & + \\
\hline Notra & Number of training & Continuous & + \\
\hline Grpm & Group membership & Dummy $1=$ yes, $0=$ no & + \\
\hline Dist & Distant to market (kilometers) & Continuous & $+/-$ \\
\hline Fexp & Farming experience(years) & Continuous & + \\
\hline Infoacc & Information access & Dummy $1=y e s, 0=$ no & + \\
\hline Rel & Reliability of the outlet & 5 Likert $=(\mathrm{SD}$ to $\mathrm{SA})$ & + \\
\hline
\end{tabular}

Note: $\mathrm{SD}=$ Strongly Disagree, $\mathrm{D}=$ Disagree, $\mathrm{N}=$ Neutral, $\mathrm{A}=$ Agree, $\mathrm{SA}=$ Strongly Agree

Table 2: Descriptive statistics of farm, farmer and vertical coordination attributes for continuous variables

\begin{tabular}{lllll}
\hline Variables & All $(215)$ & $\begin{array}{l}\text { Contract } \\
\text { Mean }\end{array}$ & $\begin{array}{l}\text { Non-Contract } \\
\text { Mean }\end{array}$ & t-value \\
\hline Age & $46.4(12.53)$ & $46.9(12.66)$ & $45.7(12.36)$ & -0.679 \\
Education of the respondent & $9.71(3.45)$ & $10.17(3.74)$ & $8.97(3.18)$ & $-2.514^{* *}$ \\
Education stock & $38.3(19.93)$ & $37.4(19.87)$ & $39.6(20.05)$ & 0.774 \\
Household size (number) & $4.4(2.02)$ & $4.2(1.94)$ & $4.7(2.11)$ & $-2.514^{* *}$ \\
Household size (adult equivalent) & $3.9(1.78)$ & $3.72(1.71)$ & $4.2(1.85)$ & $1.924^{* *}$ \\
Farm size (acres) & $1.26(0.94)$ & $1.33(0.95)$ & $1.14(0.91)$ & -1.475 \\
Land under French beans & $0.4(0.29)$ & $0.44(0.29)$ & $0.35(0.29)$ & $-2.311^{* *}$ \\
Farming experience & $10.33(6.86)$ & $13.75(6.28)$ & $4.9(3.34)$ & $-11.832^{* * *}$ \\
Number of training & $3.3(3.05)$ & $4.8(2.86)$ & $0.95(1.50)$ & $-11.205^{* * *}$ \\
Credit in KES & $2604(9548)$ & $3007(10857)$ & $1964(70001)$ & -0.780 \\
Distance to market center & $3.8(1.86)$ & $3.8(1.94)$ & $4.0(1.72)$ & 1.006 \\
Availability of the channel & $3.6(0.78)$ & $3.8(0.66)$ & $3.2(0.80)$ & $-6.253^{* * *}$ \\
Reliability of the channel & $3.3(0.77)$ & $3.6(0.68)$ & $2.8(0.65)$ & $-8.744^{* * *}$ \\
\hline
\end{tabular}

Note: $* * *, * *$ denotes statistical significance at $1 \%$ and $5 \%$ level respectively.

Figures in parenthesis are standard deviations associated with means of the variables indicated.

Source: survey data 2020 
Table 3: Descriptive statistics of farm and farmer characteristics for categorical variables

\begin{tabular}{|c|c|c|c|c|c|}
\hline \multicolumn{2}{|l|}{ Variables } & $\begin{array}{l}\text { All } \\
\%\end{array}$ & $\begin{array}{l}\text { Contract } \\
\%\end{array}$ & $\begin{array}{l}\text { Non-Contract } \\
\%\end{array}$ & Chi2 \\
\hline \multicolumn{6}{|c|}{ Farmer characteristics } \\
\hline \multirow[t]{2}{*}{ Gender } & Male & 60.47 & 57.58 & 65.06 & 1.194 \\
\hline & Female & 39.53 & 42.42 & 34.94 & \\
\hline \multirow[t]{3}{*}{ Marital status } & Married & 75.81 & 71.21 & 83.13 & $5.515^{*}$ \\
\hline & Single & 15.35 & 16.67 & 13.25 & \\
\hline & Widowed & 8.84 & 12.12 & 3.61 & \\
\hline \multirow[t]{4}{*}{ Occupation } & Business & 2.33 & 2.27 & 2.41 & $12.864 * * *$ \\
\hline & Casual & 1.86 & 0.00 & 4.82 & \\
\hline & Farmer & 86.98 & 84.85 & 90.36 & \\
\hline & Civil servant & 8.84 & 12.88 & 2.41 & \\
\hline \multirow[t]{2}{*}{ Off-farm income } & Yes & 27.44 & 32.58 & 19.28 & $4.526 * *$ \\
\hline & No & 72.56 & 67.42 & 80.72 & \\
\hline \multirow[t]{2}{*}{ Land ownership } & Yes & 79.53 & 81.06 & 77.11 & 0.4890 \\
\hline & No & 20.47 & 18.94 & 22.89 & \\
\hline \multirow[t]{2}{*}{ Rented-in land } & Yes & 68.37 & 68.18 & 68.67 & 0.005 \\
\hline & No & 31.63 & 31.82 & 31.33 & \\
\hline \multicolumn{6}{|l|}{ Institutional factors } \\
\hline \multirow[t]{2}{*}{ Information access } & Yes & 76.74 & 83.33 & 66.27 & $8.318 * * *$ \\
\hline & No & 23.26 & 16.67 & 33.73 & \\
\hline \multirow[t]{2}{*}{ Extension access } & Yes & 61.40 & 76.52 & 37.35 & $32.980 * * *$ \\
\hline & No & 38.60 & 23.48 & 62.65 & \\
\hline \multirow[t]{2}{*}{ Training access } & Yes & 69.30 & 86.36 & 42.17 & $46.785 * * *$ \\
\hline & No & 30.70 & 13.64 & 57.83 & \\
\hline \multirow[t]{2}{*}{ Group membership } & Yes & 62.33 & 74.24 & 43.37 & $20.680 * * * *$ \\
\hline & No & 37.67 & 25.76 & 56.63 & \\
\hline \multirow[t]{2}{*}{ Credit access } & Yes & 10.7 & 10.61 & 10.84 & $0.956 * * *$ \\
\hline & No & 89.30 & 89.39 & 89.16 & \\
\hline
\end{tabular}

Note: ***,*** denotes statistical significance at $1 \%, 5 \%$ and $10 \%$ level. Source: Survey data (2020).

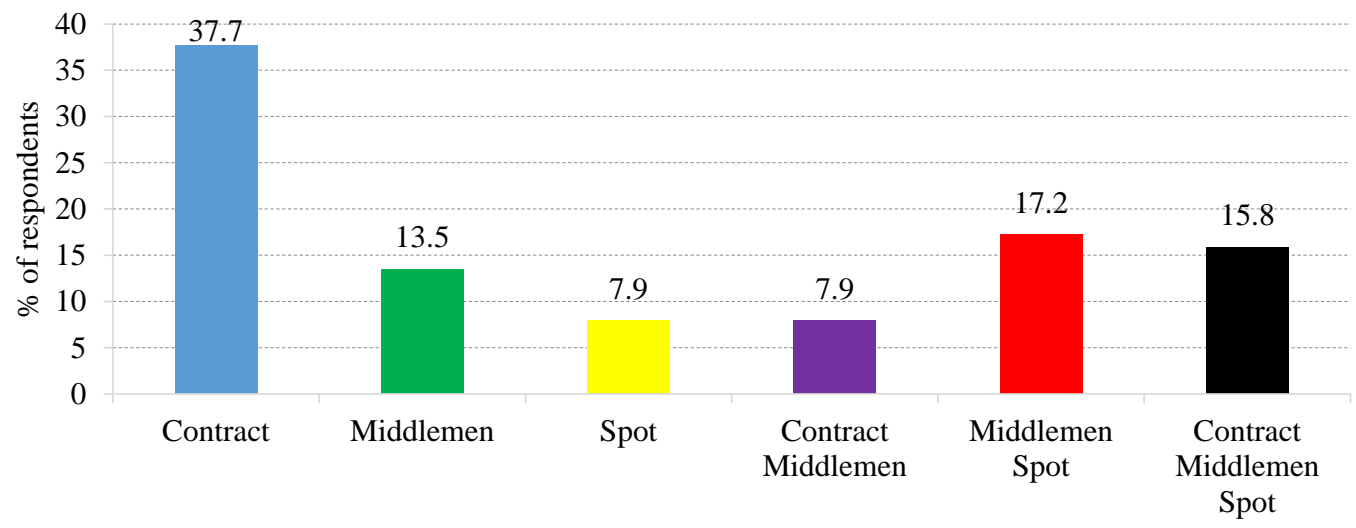

Figure 1: Vertical coordination options used by smallholder farmers

Source: survey data (2020)

\section{Empirical results}

Table 5 gives the empirical results for factors influencing the choice of vertical coordination options among smallholder farmers.

The Wald chi-square test that all the regression beta coefficients are jointly equal to zero is rejected. (Wald chisquare $(42)=131.69$; Prob $>$ chi-square $=0.0000)$. These imply that all the explanatory variables are significant. The likelihood ratio test (LR test: Chi-square (3) = 33.359; Prob > chi-square $=0$ ) is highly significant at $1 \%$ suggesting that multivariate probit model fits well the data.
Gender of the household head had a highly significant influence on the probability of choosing contract and middlemen options at $1 \%$ significance level each. Maleheaded households had a higher likelihood of selling through middlemen by $4 \%$ and a lower probability of selling through contract by $9 \%$. This implies that households headed by males were more likely to participate in middlemen options while less likely to select contract outlet. A possible explanation for the shift of males from contract to middlemen is that access to middlemen could reduce transport cost and market risks associated with the produces' perishability. Further, quick payment plays a crucial role while farmers make decisions 
on which marketing channel to use as reported by the respondents during the interviews. This finding is in line with that of Adugna et al. (2019), where farmers chose farm gate outlets to reduce transaction cost and cash constraints. However, Shammah et al. (2017) pointed out that male-headed households had a higher probability of selling pineapple in the export market than farm gate. According to Shammah et al. (2017), men have the ability to engage in negotiations, possess more marketing networks and interact with more buyers, unlike women who are restricted by family roles.

Household size had a negative and significant effect on the choice of contract option at 5\% level. Any additional adult to a household reduced the chances of participation in the contract by $47.7 \%$. An additional member could imply more responsibilities to care for the aged thus increasing the family expenditure on food and other basic needs. An increased dependency ratio in a household would mean that less money is left to pay for contract requirements such as registration fees. This result conforms to that of Muricho et al. (2015) which indicated that a higher dependency ratio puts more pressure on market participants to meet home consumption needs. However, Abu et al. (2016) found that household size had positive and negative effects on market participation. The authors argued that an increase in the number of family members could enhance market participation through the provision of labour and also reduce the probability of participating in multiple market outlets due to the limited surplus available for sale.

Education stock was positive and statistically significant at $10 \%$ for the choice of contract option. Households with higher education stock were more likely to participate in the contract as opposed to non-contract options. A one-year increase in the number of formal schooling among household members resulted in a $3 \%$ likelihood that a household will choose a contract. This implies that better-educated household members are more likely to have improved access to market information thereby affecting their decision-making. Access to this information places farmers in a better position to negotiate for better output prices, seek better market opportunities, and meet the required market quality standards. This result corroborates with studies showing that education has a positive impact on the producers' choice of market channel (Mariyono et al., 2019; Slamet et al., 2017).

Off-farm income had a positive effect on the choice of middlemen and spot market options at $1 \%$ significance level each. Involvement in off-farm activities increased the probability of participating in middlemen and spot market options by $62.8 \%$ and $62.5 \%$ respectively. A probable explanation for this is that farmers prefer to sell to channels that reduce the transaction cost involved in searching for the buyer. This result tallies with that of Emana et al. (2015) who noted that farmers with off-farm income would prefer to sell their produce to the nearby market channel with lower prices than searching for other channels. However, Muthini et al. (2017) reported that farmers with off-farm income were less likely to sell to brokers. The contradicting authors argued that these farmers probably were not cash-constrained and therefore could delay their sales as they seek better prices from other channels.

Access to extension service was found to be significant for the selection of contract and middlemen options at $5 \%$ and $1 \%$ significance levels respectively. Producers who received extension services were more likely to select contract by $67.4 \%$ while less likely to choose the middlemen option by $69.4 \%$. Extension agents provide advisory services to farmers which in turn, increases their ability to choose the best market channels such as contracts. Similarly, Muthini et al. (2017) reported that lack of extension services positively influenced the quantity of output sold to brokers. Moreover, Hirpesa et al. (2020) argued that access to extension services significantly increased the likelihood that a smallholder dairy farmer would participate in the contract market relative to the non-contract supply chain.

Number of training was positive and statistically significant at $5 \%$ level for the contract option. A unit increase in the number of training increased the probability of choosing a contract option by $18.1 \%$. This result suggests that training exposes farmers to a wide range of ideas and gives farmers opportunities to have better access to appropriate market information. Similarly, Taregken et al. 2017 noted that frequent training on improved production methods enabled farmers to access high-value channels.

Group membership was positive and statistically significant at $10 \%$ for the contract channel. Farmers belonging to an agricultural group had a higher probability of selling through a contract outlet by $55.4 \%$. This can be attributed to the fact that producers who collectively market their produce to distant areas tended to incur reduced transaction cost. It may further be explained by the role of collective action in attaining bargaining power and reducing transaction cost which corroborates with findings by Mulbah et al. (2020). This finding is also consistent with those of Kiprop et al. (2020) which stated that the probability of accessing processor market outlets increased with group membership as compared to accessing the market as an individual producer. However, group membership can negatively impact market participation in case disagreement emerges among members, distorting marketing decisions (Olwande \& Mathenge, 2012).

Access to credit was positive and statically significant at $10 \%$ for the contract channel. A unit increase in credit received increased the chances of participating in the contract option. A possible explanation for this is that obtaining a contract market for French beans is both labour and capital-intensive and therefore credit access eases the liquidity constraint of households. Similarly, Melese $\boldsymbol{e t}$ al. (2018) found that the availability of credit services had a positive significant effect on the choice of assemblers as a viable marketing channel for selling onions as opposed to direct consumers.

Farming experience was highly significant at $1 \%$ significance level for contract and spot market. An additional year of farming experience increased the probability of selling through contract option by $22.3 \%$ while less experience was associated with selling a larger proportion of output to the spot market by $9 \%$. Farmers 
who had more farming experience were assumed to have better bargaining power and marketing linkage, and therefore, were able to understand opportunities and threats in the market. These producers, thereby, tended to sell their produce to the contract option because it offered farm inputs. Hung \& Bokelmann, (2019) found a similar result.

Perception on the reliability of the outlet was statistically significant at $5 \%, 1 \%$ and $1 \%$ significance level for contract, middlemen and spot market respectively. High perception of reliability of the channel increased the probability of choosing a contract option by $62.1 \%$ while reducing the likelihood of selling through middlemen and spot market by $54.9 \%$ and $36.6 \%$ respectively. With the perishable nature of French beans, producers tend to choose market channels that have a ready market to supply their produce. This implies that contract attributes such as stable market prices, availability of market information, timely payments and guaranteed market motivated farmers to sell their produce through this channel. This result is in line with Dlamini $\boldsymbol{e t}$ al. (2019) who reported that market incentives such as bulk purchasing, quick process and lump sum payments encouraged farmers to sell through supermarkets compared to traditional markets.
Distance to the market center was positive and statistically significant at $10 \%$ for the contract option. A unit increase in distance to market increased the likelihood of choosing a contract by $3 \%$. This implies that the probability of choosing a contract option increases with an additional distance to the market center. A plausible explanation for this behaviour could be, farmers incurred extra transaction cost while moving their produce to the market and thus they preferred to sell through contract since it provides transport for their produce. Similarly, Shammah et al. (2017) noted that additional distance to the market increased the probability of choosing an export market for pineapple fruits as opposed to the farm gate. According to the authors, gross margin from a high-value channel outweighs the opportunity cost of selling the produce at the farm gate due to transaction cost incurred. Additionally, farmers who are farther from the market are more likely to have large farms which exporters prefer because of economies of scale (Muthini et al., 2017). However, Van den Berg et al. (2004) argued that small farms owned by resource-rich farmers, not relying on family labour, perform better than large farmers owned by resource-poor farmers.

Table 4: Pairwise correlation test for categorical variables

\begin{tabular}{lllllll}
\hline & Gender & $\begin{array}{l}\text { Extensio } \\
\mathrm{n} \text { access }\end{array}$ & $\begin{array}{l}\text { Training } \\
\text { access }\end{array}$ & $\begin{array}{l}\text { Off-farm } \\
\text { income }\end{array}$ & $\begin{array}{l}\text { Group } \\
\text { membership }\end{array}$ & $\begin{array}{l}\text { Information } \\
\text { access }\end{array}$ \\
\hline Gender & 1 & & & & & \\
Extension access & -0.1136 & 1 & & & & \\
Training access & -0.0225 & 0.2593 & 1 & & & \\
Off-farm income & 0.0496 & 0.1023 & 0.2059 & 1 & & \\
Group & -0.0594 & 0.1327 & 0.2317 & 0.0694 & 1 & 1 \\
membership & & & & & & \\
Information access & -0.1524 & 0.1741 & 0.2542 & 0.1412 & 0.1855 & 1 \\
\hline
\end{tabular}

Table 5: MVP estimates for factors influencing VCO selection decisions

\begin{tabular}{lllllll}
\hline Variable & Contract & \multicolumn{4}{l}{ Middlemen } & Spot \\
& Coeff. & Std.Err & Coeff. & Std.Err & Coeff. & Std.Err \\
\hline Age & -0.014 & 0.015 & 0.010 & 0.010 & 0.014 & 0.010 \\
Gender & $-0.948^{* * *}$ & 0.352 & $0.407 * * *$ & 0.207 & 0.105 & 0.206 \\
Household size & $-0.457 * *$ & 0.184 & 0.044 & 0.093 & -0.112 & 0.095 \\
Education stock & $0.031 *$ & 0.017 & 0.002 & 0.009 & 0.013 & 0.009 \\
Farm size & -0.104 & 0.173 & 0.001 & 0.124 & -0.017 & 0.116 \\
Off-farm income & 0.308 & 0.363 & $0.628^{* * *}$ & 0.237 & $0.625 * * *$ & 0.237 \\
Group membership & $0.554^{*}$ & 0.322 & -0.326 & 0.225 & 0.009 & 0.215 \\
Extension access & $0.674 * *$ & 0.330 & $-0.694 * * *$ & 0.222 & -0.156 & 0.221 \\
Number of training & $0.181 * *$ & 0.089 & -0.021 & 0.045 & 0.038 & 0.051 \\
Reliability & $0.621 * *$ & 0.190 & $-0.549 * * *$ & 0.148 & $-0.366 * * *$ & 0.141 \\
Distance & $0.039 *$ & 0.023 & -0.020 & 0.015 & -0.015 & 0.014 \\
Farming experience & $0.223 * * *$ & 0.052 & -0.005 & 0.021 & $-0.092 * * *$ & 0.028 \\
Information access & -0.151 & 0.378 & 0.061 & 0.248 & 0.311 & 0.238 \\
Credit access & $0.000^{*}$ & 0.000 & 0.000 & 0.000 & 0.000 & 0.000 \\
cons & -3.113 & 1.065 & 1.724 & 0.692 & 0.809 & 0.670 \\
\hline
\end{tabular}

Number of observations $=215$

L.R test of rho30 $=$ rho31 $=$ rho32 $=0 \quad$ Chi2 $(3)=33.359 \quad$ Prob $>$ chi $2=0.0000$

Wald chi2 $(42)=131.69 \quad$ Prob $>$ chi $2=0.0000$

Note: $* * *, * * *$ denotes statistical significance at $1 \%, 5 \%$ and $10 \%$ level respectively.

Source: survey data 2020 


\section{CONCLUSION AND POLICY RECOMMENDATION}

Kenya operates under imperfect input and output market resulting in high transaction cost, price risks and thin markets. The study focuses on determinants of vertical coordination option choices based on data collected from smallholder French beans producers in Murang'a South Sub-County. The findings show that gender, household size, education, group membership, extension access, number of training, market reliability, farming experience, credit access, off-farm income and distance to market have a significant effect in explaining farmers' vertical coordination option selection strategy. The study also revealed that French beans were marketed through a single or combination of channels. Further, the findings established that the Contract option was the dominant channel among smallholder French beans producers.

The following are policy recommendations drawn from the study. First, there is a need to strengthen rural farmer organizations to increase their bargaining power and borrowing ability. Distance from the farm to the market significantly influenced vertical coordination choice decisions. This study recommends investing in infrastructure, especially roads, to reduce transaction cost and improve supply reliability. Household size was negative and statistically significant for the choice of contract option. This result brings forward the importance of demographic policy, which takes into account the households' composition. Therefore, this study recommends the need for policy geared towards helping farmers with a high dependency ratio to improve their household income. Farming experience was highly significant for the choice of contract market option. Therefore, the government needs to organize more training on the new Global GAPs, especially for older farmers. This move would enable farmers to meet highvalue market requirements. Access to credit was found critical in driving uptake of formal French beans marketing channel. Financial institutions stakeholders should develop policies that favour the acquisition of credit at affordable rates.

\section{REFERENCES}

ABATE, T. M., MEKIE, T. M., \& DESSIE, A. B. (2019). Determinants of market outlet choices by smallholder teff farmers in Dera district, South Gondar Zone, Amhara National Regional State, Ethiopia: a multivariate probit approach. Journal of Economic Structures, 8(1),

39. https://link.springer.com/article/10.1186/s40008-0190167-x

ABASIMEL, N. A. (2020). Determinants of coffee market outlet choice by smallholder farmers in Seka Chokorsa district, Jimma Zone, Ethiopia. World Journal of Agricultural Sciences, 16(2), 111-124. DOI: $10.7176 /$ JPID/54-03

ABDALLAH, A. H. (2016). Does credit market inefficiency affect technology adoption? Evidence from Sub-Saharan Africa. Agricultural Finance Review, 76(4), 494-511. https://doi.org/10.1108/AFR$\underline{05-2016-0052}$
ABU, B. M., ISSAHAKU, H., \& NKEGBE P. K. (2016) Farmgate versus market centre sales: a multi-crop approach." Agricultural and Food Economics, 4(1), 21.

https://agrifoodecon.springeropen.com/articles/10.11 86/s40100-016-0065-6

ADUGNA, M., KETEMA, M., GOSHU, D., \& DEBEBE, S. (2019). Market outlet choice decision and its effect on income and productivity of smallholder vegetable producers in lake Tana Basin, Ethiopia. Review of Agricultural and Applied Economics (RAAE), 22(1), 83-90. http://dx.doi.org/10.22004/ag.econ.285934

AGHOLOR, A. I. (2019). Gender gap in Sub-Saharan Africa, reminiscence of rural extension and advisory services: delineation, challenges and strategies. South African Journal of Agricultural Extension, 47(3), 46$60 . \quad$ http://dx.doi.org/10.17159/24133221/2019/v47n3a514

AYINDE, O. E., IBRAHIM, H. K., SALAMI, M. F., \& AJIBOLA, L. E. (2017). Effect of vertical integration on multidimensional well-being of fish farmers in Lagos State Fish-hub, Nigeria. Agricultural Tropical and Subtropical, $50(2), \quad 81-87$. https://doi.org/10.1515/ats-2017-0009

BA, H. A., DE MEY, Y., THORON, S., \& DEMONT, M. (2019). Inclusiveness of contract farming along the vertical coordination continuum: Evidence from the Vietnamese rice sector. Land Use Policy, 87, 104050. https://doi.org/10.1016/j.landusepol.2019.104050

BARRETT, C. B., BACHKE, M. E., BELLEMARE, M. F., MICHELSON, H. C., NARAYANAN, S., \& WALKER, T. F. (2012). Smallholder participation in contract farming: comparative evidence from five countries. World Development, 40(4), 715-730. https://doi.org/10.1016/j.worlddev.2011.09.006

BARRETT, C. B. (2010). Smallholder market participation: Concepts and evidence from eastern and southern Africa. Food security in Africa. https://doi.org/10.4337/9781849806367.00008

BELDERBOS, R., CARREE, M., DIEDEREN, B., LOKSHIN, B., \& VEUGELERS, R. (2004). Heterogeneity in research and development cooperation strategies. International Journal of Industrial Organizations, 22(8-9), 1237-1263. https://doi.org/10.1016/j.ijindorg.2004.08.001

BITSCH, L., ATOYAN, S., RICHTER, B., HANF, J., \& GAGALYUK, T. (2020). Including smallholders with vertical coordination. https://doi.org/10.5772/intechopen.92395

BURKITBAYEVA, S., JANSSEN, E., \& SWINNEN, J. (2020). Technology adoption, vertical coordination in value chains, and FDI in developing countries: panel evidence from the dairy sector in India (Punjab). Review of Industrial Organization, 57, 433479.

https://link.springer.com/content/pdf/10.1007/s11151 -020-09763-1.pdf

CARILLO, F., CARACCIOLO, F., \& CEMBALO, L. (2017). Do farms benefit from vertical coordination? Evidence from Italian durum wheat producers. Agricultural Food Economics, 5(1), 1-13. https://doi.org/10.1186/s40100-017-0088-7 
CARILLO, F. (2016). Vertical integration in Italian pasta supply chain: A farm-level analysis. Journal of Agricultural Economics, 71(1), 47-66. https://doi.org/10.13128/REA-18377

CILIBERTI, S., FRASCARELLI, A., \& MARTINO, G. (2020). Drivers of participation in collective arrangements in the agri-food supply chain. Evidence from Italy using a transaction costs economics perspective. Annals of Public and Cooperative Economics, 91(3), 387-409. https://doi.org/10.1111/apce.12263

COUNTY GOVERNMENT OF MURANG'A (2018). Murang'a County Integrated Development Plan (2018-2022).

DESSIE, A. B., ABATE, T. M., \& MEKIE, T. M. (2018). Factors affecting market outlet choice of wheat producers in North Gondar Zone, Ethiopia. Agriculture \& Food Security, 7(1), 1-8. https://link.springer.com/article/10.1186/s40066-018$\underline{0241-\mathrm{X}}$

DLAMINI-MAZIBUKO, B. P., FERRER, S., \& ORTMANN, G. (2019). Factors affecting the choice of marketing outlet selection strategies by smallholder farmers in Swaziland. African Journal of Science, Technology, Innovation and Development, 11(5), 569577. https://doi.org/10.1080/20421338.2018.1554323

EMANA, B., AFARI-SEFA, V., DINSSA, F. F., AYANA, A., BALEMI, T., \& TEMESGEN, M. (2015). Characterization and assessment of vegetable production and marketing systems in the Humid Tropics of Ethiopia. Quarterly Journal of International Agriculture, 54(2), 163-187. http://dx.doi.org/10.22004/ag.econ.210313

HIRPESA, M., LEGESSE, B., HAJI, J., \& BEKELE, K (2020). Determinants of participation in contract farming among smallholder dairy farmers: the case of North Shewa Zone of Oromia National Regional State, Ethiopia. Sustainable Agriculture Research, 10(1), 1019. http://dx.doi.org/10.22004/ag.econ.309795

HUNG ANH, N., \& BOKELMANN, W. (2019). Determinants of smallholders' market preferences: The case of sustainable certified coffee farmers in Vietnam. Sustainability, 11(10), 2897. https://doi.org/10.3390/su11102897

KNBS. (2019). Kenya population and housing census by county and sub-county 1 .

ISLAM, A. H. M., ROY, D., KUMAR, A., TRIPATHI, G., \& JOSHI, P. K. (2019). Dairy contract farming in Bangladesh: Implications for welfare and food safety. International Food Policy Research Institute, (Vol. 1833). https://doi.org/10.2499/p15738coll2.133227

KIPROP, E. K., OKINDA, C., AKTER, A., \& GENG, X. (2020). Factors influencing marketing channel choices for improved indigenous chicken farmers: insights from Baringo, Kenya. British Food Journal, 22(12), 3797-3813. $\quad$ https://doi.org/10.1108/BFJ-11-2019$\underline{0841}$

KIWANUKA, R. N., \& MACHETHE, C. (2016). Determinants of smallholder farmers' participation in the Zambian dairy sector's interlocked contractual arrangements. Journal of Sustainable Development, 9(2), 230-245. http://dx.doi.org/10.5539/jsd.v9n2p230
MARIYONO, J., WASKITO, J., KUNTARININGSIH, A., GUNISTIYO, G., \& SUMARNO, S. (2019). Distribution channels of vegetable industry in Indonesia: impact on business performance. International Journal of Productivity and Performance Management, 69(5), 963-987. https://doi.org/10.1108/IJPPM-11-2018-0382

MASPAITELLA. M., GARNEVSKA, E., SIDDIQUE, M. I., \& SHADBOLT, N. (2018). Towards high-value markets: a case study of smallholder vegetable farmers in Indonesia. International Food and Agribusiness Management Review, 21(1), 73-88. http://dx.doi.org/10.22004/ag.econ.266450

MELESE, T., GOSHU, D., \& TILAHUN, A. (2018). Determinants of outlet choices by smallholder onion farmers in Fogera district Amhara Region, Northwestern Ethiopia. Journal of Horticulture and Forestry, 10(3), $27-35$. https://doi.org/10.5897/JHF2018.0524

MMBANDO, F. E., WALE, E., BAIYEGUNHI, L. J. S., \& DARROCH, M. A. G. (2016). The choice of marketing channel by maize and pigeonpea smallholder farmers: evidence from the northern and eastern zones of Tanzania. Agrekon, 55(3), 254-277. https://doi.org/10.1080/03031853.2016.1203803

MOJO, D., FISCHER, C., \& DEGEFA, T. (2017). The determinants and economic impacts of membership in coffee farmer cooperatives: recent evidence from rural Ethiopia. Journal of Rural studies, 50, 84-94. https://doi.org/10.1016/j.jrurstud.2016.12.010

MOUNIROU, I. (2020). Does participation in contracts affect agricultural income? An empirical evidence from parboiled rice farmers in central Benin. Cogent Food and Agriculture, 6(1), 1800237. https://doi.org/10.1080/23311932.2020.1800237

MULBAH, F. F., RITHO, C., \& MBURU, J. (2020). Do transaction costs influence smallholder rubber farmers' choice of selling outlets? Evidence from Liberia. Development in Practice, 31(1), 69-80. https://doi.org/10.1080/09614524.2020.1789068

MURICHO, G., KASSIE, M., \& OBARE, G. (2015). Determinants of market participation regimes among smallholder maize producers in Kenya (No. 1008-2016-80186). http://dx.doi.org/10.22004/ag.econ.212515

MUTHINI, D. N., NYIKAL, R. A., \& OTIENO, D. J. (2017). Determinants of small-scale mango farmers market channel choices in Kenya: An application of the two-step Craggs estimation procedure. Journal of Development and Agricultural Economics, 9(5), 111120. DOI: 10.5897/JDAE2016.0773

NANDI, R., GOWDRU, N. V., \& BOKELMANN, W. (2017). Factors influencing smallholder farmers in supplying organic fruits and vegetables to supermarket supply chains in Karnataka, India: a transaction cost approach. International journal of rural management, 13(1), 85-107. https://doi.org/10.1177\%2F0973005216689319

NYAUPANE, N. P., \& GILLESPIE, J. M. (2011). Factors influencing producers' marketing decisions in the Louisiana crawfish industry. Journal of Food 
Distribution Research, 42(2), 1-11. http://dx.doi.org/10.22004/ag.econ.139420

OLWANDE, J., \& MATHENGE, M. (2012). Market Participation among the poor rural 178 households in Kenya. A paper prepared for presentation at the International Association of Agricultural Economists (IAAE) Triennial Conference, Foz do Iguaçu, Brazil. Foz do Iguaçu, Brazil.

PASCUCCI, S., \& GARDEBROEK, C. (2010). Some like to join, others to deliver. An econometric analysis of farmers' relationships with agricultural cooperatives (No. 699-2016-47928).

PETERSON, H. C., WYSOCKI, A., \& HARSH, S. B. (2001). Strategic choice along the vertical coordination continuum. The International Food and Agribusiness Management Review, 4(2), 149-166. https://doi.org/10.1016/S1096-7508(01)00079-9

SAENGER, C., QAIM, M., TORERO, M., \& VICEISZA, A. (2013). Contract farming and smallholder incentives to produce high quality: experimental evidence from the Vietnamese dairy sector. Agricultural Economics, 44(3), 297-308. https://doi.org/10.1111/agec.12012

SCHIPMANN, C., \& QAIM, M. (2011). Supply chain differentiation, contract agriculture, and farmer's marketing preferences: The case of sweet pepper in Thailand. Food policy, 36(5), 667-677. https://doi.org/10.1016/i.foodpol.2011.07.004

SLAMET, A. S., NAKAYASU, A., \& ICHIKAWA, M. (2017). Small-scale vegetable farmers' participation in modern retail market channels in Indonesia: the determinants of and effects on their income. Agriculture, 7(2),

11. https://doi.org/10.3390/agriculture7020011

SHAMMAH, A., MSHENGA, P., \& AYUYA, O. I. (2017). Analysis of risk attitudes and social capital in pineapple marketing: The case of small-scale farmers in Luwero district, Uganda. African Journal of Rural Development, 2(2), 235-246. https://www.afjrd.org/jos/index.php/afjrd/article/view $\underline{1153}$

SIGEI, G., BETT, H., \& KIBET, L. (2014). Determinants of market participation among small-scale pineapple farmers in Kericho County, Kenya. MPRA Paper. https://mpra.ub.uni-muenchen.de/56149/

SINGH, S. (2002). Contracting out solutions: Political economy of contract farming in the Indian Punjab. World Development 30(9), 1621-1638. https://doi.org/10.1016/S0305-750X(02)00059-1

TAREKEGN, K., HAJI, J., \& TEGEGNE, B. (2017). Determinants of honey producer market outlet choice in Chena District, southern Ethiopia: A multivariate probit regression analysis. Agricultural and food economics, 5(1),

$1-14$. https://link.springer.com/article/10.1186/s40100-017$\underline{0090-0}$

TRIFKOVIC, N. (2016). Vertical coordination and farm performance: evidence from the catfish Sector in Vietnam. Agricultural Economics, 47(5), 547-557. https://doi.org/10.1111/agec.12254

VAN DEN BERG, M. M., HENGSDIJK, H., WOLF, J., VAN ITTERSUM, M. K., GUANGHUO, W., \&
ROETTER, R. P. (2007). The impact of increasing farm size and mechanization on rural income and rice production in Zhejiang province, China. Agricultural Systems, 94(3), 841-850. https://doi.org/10.1016/j.agsy.2006.11.010

VROEGINDEWEY, R., THERIAULT, V., \& STAATZ, J. (2018). Coordinating cereal farmers and buyers: evidence from Mali. Journal of Agribusiness in Developing and Emerging Economies. 8(2), 234-255. https://doi.org/10.1108/JADEE-11-2016-0075

WOLLNI, M., ROMERO, C., SAENZ, F., \& LE COQ, J. F. (2012). Vertical coordination and standard adoption: evidence from the Costa Rican pineapple sector. Communication presented to the IAAE Preconference workshop The changing interface between public and private standard setting: implications for sustainability in food supply chains, 14 /08 /2012, Sao Paulo, Brazil. https://agritrop.cirad.fr/567288/1/document 567288.p $\underline{\text { df }}$

WOSENE, G., KETEME, M., \& ADEME, A. (2018). Factors affecting market outlet for pepper producers in Wonberma District, Northern Ethiopia: multivariate probit approach. Cogent Food and Agriculture, 4(1), 1558497. https://doi.org/10.1080/23311932.2018.1558497

YAMANE, T. (1967). Statistics: An Introductory Analysis, 2nd edition. New York: Harper and Row. 